\title{
Extensão universitária ferramenta de participação social não formal: contribuição de estudantes do ensino médio
}

\author{
University extension social non-formal participation tool: contribution of
} high school students

\section{Extensión universitaria herramienta de participación social no formal: contrición de estudiantes de secundaria}

\author{
João Aparecido Bazzoli ${ }^{1}$ \\ http://orcid.org/0000-0002-7123-2023 \\ Maria da Vitoria Costa Silva 2 \\ iD https://orcid.org/0000-0002-1753-3351 \\ Tatiana de Oliveira Sousa ${ }^{3}$ \\ https://orcid.org/0000-0003-3005-3544
}

\begin{abstract}
Resumo: Este estudo objetivou compreender a extensão universitária como meio de instigar estudantes do ensino médio a participação social. Buscou-se despertar nos estudantes das escolas públicas de ensino médio a cidadania a partir da identificação de problemas urbanos e proposições de resoluções para estes problemas. Este estudo constatou que o mecanismo não formal de extensão se apresenta como um modo alternativo adequado e efetivo de inserção dos estudantes secundários nos debates sobre a cidade. A metodologia qualitativa aplicada nesta pesquisa partiu da análise das ações e dos resultados das atividades do projeto "Nós propomos" realizadas pelos estudantes de seis escolas estaduais em Palmas durante o ano de 2017. Concluiu-se que a extensão universitária possibilita experimentar novas ferramentas participativas não formais adequadas para a inserção de estudantes secundaristas na participação social.

Palavras-chave: Cidadania. Participação Social. Nós propomos. Extensão universitária.
\end{abstract}

Abstract: This study aimed to understand the universitary extension as a means of high school studants to social participation. Sough to show to the public school high students the citizenship from the identification of

1 Professor na Universidade Federal do Tocantins (UFT) do Curso de Direito. Docente Permanente do Programa de Pós-graduação em Desenvolvimento Regional (PPGDR/UFT).

E-mail: jbazzoli@uft.edu.br

2 Colaboradora da Universidade Federal do Tocantins (UFT), nos projetos: Palmas Participa, Nós Propomos e Cidade e Meio ambiente: Estudo ampliado em Perspectiva Interdisciplinar.

E-mail:mavitcs@gmail.com

3 Membro do Projeto de Extensão Palmas Participa; Membro Voluntários do Projeto de Extensão Nós Propomos - Universidade Federal do Tocantins - UFT.

E-mail: tatyanaoliveirasousa@gmail.com 
the urban problems and preposition of resolutions for this problems. The study checked to see if the non-formal mecanism of the extension show as alternative way appropriate and effective of secondary student's insertion in the discussions of citizenship in the debates of the city. The qualitative metodology applied in this research started of the analysis of the actions and results of the projecto "We Propose" performed by the students from six public schools in Palmas during the year 2017. Concluded that the universitary extention makes possilble to experiment new participatory tools appropriate non-formal and promotes the integration of students in social participation.

Keywords: Citizenship. Socia Participation. "We Propose". Universitary extension.

Resumen: Este estudio objetivó comprender la extensión universitaria como medio de instigar a estudiantes de la enseñanza media a la participación social. Se buscó despertar en los estudiantes de las escuelas públicas de enseñanza media la ciudadanía a partir de la identificación de problemas urbanos y proposiciones de resoluciones para estos problemas. Este estudio constató que el mecanismo no formal de extensión se presenta como un modo alternativo adecuado y efectivo de inserción de los estudiantes secundarios en los debates sobre la ciudad. La metodología cualitativa aplicada en esta investigación partió del análisis de las acciones y de los resultados de las actividades del proyecto "Nosotros Proponemos" realizadas por los estudiantes de seis escuelas estatales en Palmas durante el año 2017 Se concluyó que la extensión universitaria posibilita experimentar nuevas herramientas participativas no formales adecuadas para la inserción de estudiantes secundarios en la participación social.

Palabras clave: Ciudadanía. Participación Social. Nosotros Proponemos. Extensión Universitaria.

\section{INTRODUÇÃO}

Este trabalho ao propor reflexão sobre os desafios complexos e inéditos, que a sociedade do século XXI enfrenta, tenta mostrar que a população brasileira está sendo chamada a acompanhar o debate acerca das crises política e econômica, que de certa maneira tem abalado as estruturas da democracia, com vista a evitar a vulneração dos direitos humanos. Neste contexto se pode afirmar que o País vive momentos difíceis advindos de "uma crise profunda de transformação social e econômica, que tem suas raízes no passado". (BAUMAN, BORDONI, 2016, p. 75). Entretanto, a democracia direta pela participação social não informal poderá ser um importante instrumento na construção de um novo paradigma.

Com a globalização econômica neoliberal e os novos contornos tecnológicos que ampliam o acesso à informação, ao consumismo e à ascensão do mercado, a modernidade experimenta a dura travessia da passagem da fase sólida para a líquida, ou seja, as organizações sociais e as instituições de Estado não podem mais manter sua forma estrutural por muito tempo. (BAUMAN, BORDONI, 2016, p. 7).

Dessa maneira, esse contexto enunciado merece atenção, tanto aos olhares dos organismos internacionais, como aos dos organismos internos, a partir dos governantes, cientistas, agentes e atores sociais, no intuito de evitar práticas totalitárias. E, diante desse quadro se justifica o avanço de pesquisas que reforcem a participação e o controle social na gestão das políticas públicas locais. 
Ao considerar este cenário de acirramento do embate entre as forças hegemônica centralizadora do poder econômico neoliberal em âmbito global, e a contra-hegemônica, representadas pela construção democrática centrada no reconhecimento recíproco entre identidades e culturas distintas locais (SANTOS, 2002, pp. 74-75), espera-se encontrar um equilíbrio. Este equilíbrio deve estar respaldado do consenso criativo e da preservação dos direitos fundamentais voltado para a dignidade humana e a sustentabilidade como gênero. (HABERMAS, 2012, p. 727).

Neste viés, diante da complexidade deste quadro, a Universidade poderia assumir o desafio de protagonizar a articulação de plataformas de conhecimento que intensificassem práticas democráticas para o fomento e a inserção da população nas discussões, planejamento e na execução de políticas públicas nas cidades brasileiras.

Desta maneira, relatamos neste artigo estudo que objetivou compreender a importância da extensão universitária como alternativa para instigar a participação social de estudantes secundaristas de escolas da rede pública estadual em Palmas -TO. Para atingir este objetivo, buscou-se enfrentar paradigmas dominantes e provocar um amplo e democrático debate a respeito deste tema árido.

Nesse sentido, por meio de realização de pesquisa empírica, analisou-se a experiência do projeto de extensão "Nós propomos", atualmente desenvolvido na Universidade Federal do Tocantins (UFT), por uma equipe interdisciplinar composta pelos cursos: Direito, Arquitetura e Urbanismo, Geografia e Programa de Pós-Graduação em Desenvolvimento Regional. Este projeto acadêmico tem a finalidade de estimular os estudantes a identificar problemas locais e "elaborar propostas de soluções para problemas urbanos e socializá-las em seminário e nas instâncias comunitárias" (BAZOLLI, 2017, p. 48). Durante o desenvolvimento das ações pretende despertar nos estudantes secundaristas a cidadania ativa, para além disso, instigá-los a realizar pesquisa a apresentar propostas que sejam viáveis e criativas.

No estudo realizado para entender o "Nós propomos" foi aplicada a pesquisa-ação e metodologia qualitativa na análise das ações e dos documentos oriundos das atividades realizadas pelos estudantes do ensino médio, das seis escolas da rede pública estadual de Palmas-TO, que integram o projeto, durante o ano letivo de 2017.

Com o estudo se tentou reunir esforços de mostrar que a extensão universitária possibilita experimentar novas ferramentas participativas não formais e de certa maneira possibilita transformá-la em mecanismos de inserção dos jovens nos debates sobre o Direito à Cidade. Ponderando-se que estes mecanismos não formais de participação social se 
apresentam como um modo alternativo e adequado de inserção da juventude nos debates sobre a gestão democrática da cidade.

\section{O PAPEL DA EXTENSÃO UNIVERSITÁRIA NO SÉCULO XXI}

A partir dos desafios identificados para o século $X X I$ a educação terá a necessidade de se reinventar pensando no homem do futuro (universal, globalizado e hiperativo) e de modificar o processo de ensino-aprendizagem, ter enfoque no ensino da condição humana, movido pela razão, afetividade e a emoção. (MORIN, 2001, pp. 47-61).

Neste sentido a Universidade como colaboradora na construção do conhecimento e tendo o respaldo constitucional do art. 207, caput, (BRASIL, 1988): o de desenvolver um ambiente de aprendizado teórico-prático e de condicionar sua ação para novos desafios que emergem da sociedade, por meio da efetividade do princípio da indissociabilidade entre ensino, pesquisa e a extensão; tem de assumir o papel preponderante nesta proposta de reinvenção e da modificação desejada pela sociedade.

Portanto, essa nova dinâmica necessita de reengenharia contínua da disseminação de saberes científicos, técnicos e populares, que oportunizem aos professores e aos estudantes construírem espaços interdisciplinares de diálogos, a fim de encontrarem respostas racionais aos complexos problemas comunitários. Sendo está a dinâmica experimentada na atuação da equipe interdisciplinar no desenvolvimento das atividades do projeto "Nós propomos".

Esse esforço para concretizar esta mudança desejada pela sociedade parte do sentido de que a educação, por ter à sua frente o desafio de trabalhar com contextos difíceis, deve proporcionar aos alunos a autoconfiança e a possibilidade de recriar espaços democráticos de compartilhamento de saberes e de ações emancipadoras proativas para a construção de cidades sustentáveis, considerando o respeito ao próximo e ao Planeta.

Porquanto, esse esforço engendrado pode ser considerado o caminho para a autoformação do jovem que perpassa pelo aprendizado criativo, ou seja, compreender a arte de ensinar e assumir a condição humana nas suas três dimensões: labor, trabalho e ação. (ARENDT, 2007, p.15). E, nesse contexto, o "cidadão é definido, em uma democracia, por sua solidariedade e responsabilidade em relação à sua pátria. O que supõe nele o enraizamento de sua identidade nacional". (MORIN, 2003, pp. 63). 
Portanto, ensinar a viver com solidariedade é fortalecer a cidadania ativa, fator que se torna possível a partir do trabalho em equipe e de modo ampliado. Morin (2011) afirmou que humanidade implica o respeito aos saberes e fazeres, propôs um humanismo a partir da incorporação das experiências vividas em tempos e espaços diferente e sugeriu as práticas dos princípios de solidariedade e responsabilidade; os princípios de pluralidade e os de participação.

Dessarte, nessa linha de construção epistemológica, a extensão universitária torna-se um campo fecundo e "espaço do compartilhamento da ecologia de saberes", que corresponde a um canal facilitador para a constituição de sujeitos individuais e coletivos que combinam a maior sobriedade na análise dos fatos com a intensificação da vontade da luta contra a opressão. (SANTOS, 2006, p. 164).

Portanto, o caminho racional pretendido pela necessidade de mudança perpassa pelo conhecimento que incentive processos autônomos dos atores sociais, principalmente dos grupos minoritários excluídos da atenção do Estado. Isto ocorre a partir do estimulo à coletividade e à participação democrática no destino da gestão pública das cidades. (SANTOS, 2006, p. 164).

No Brasil, a Lei federal de No 10.257 (BRASIL, 2001), denominada Estatuto da Cidade, propõe a gestão democrática atribuindo à população e as associações representativas dos vários segmentos o direito a participar da formulação, execução e acompanhamento de planos, programas e projetos de desenvolvimento urbano. Porém, Bazolli (2017, p.47), afirma que "embora tenhamos consciência de que as cidades brasileiras estejam passando por importantes transformações", por isso o autor propõe "séria reflexão acerca da resistência ao rompimento de paradigmas ao defendermos a gestão participativa".

Desta maneira, pode-se afirmar que essa "postura ativa se concretiza por meio da ação comunicativa" (HABERMAS, 2012, p. 75) em que os atores sociais apareçam como sujeitos da reconstrução do estado democrático de direito, por meio da ação da esfera pública (HABERMAS, 2014) nas discussões sobre a qualidade e a eficiência dos serviços nos espaços urbanos comunitários.

E, neste sentido, com a aliança entre saberes científico, técnico e popular, será possível estabelecer a renovação do homem como sujeito da história e produzir reformulações de políticas públicas e de defesa do meio ambiente sustentável, à presente e futuras gerações. Assim, a partir desta dinâmica, o cidadão quando estiver diante de dificuldades buscará resoluções para os problemas a partir do próprio protagonismo. 
Observa Bazolli (2017, p. 29) ser "inadmissível ver práticas de criação de obstáculos instransponíveis ao planejamento participativo e progressista, comprometido com os objetivos de justiça social e equidade" e contrário a este viés retrógado o estudo proposto buscou identificar novas plataformas emancipatórias que contribuam efetivamente para a melhoria das políticas públicas municipais, em razão de se detectar que "absurdamente, os gestores públicos não criam espaços para a construção de projetos coletivos". (BAZOLLI, 2017, p. 29).

Neste sentido o projeto "Nós propomos" tenta "ressignificar a cidade" a partir de mudanças de paradigmas fincados "no protagonismo popular, tendo em vista a força participativa e a igualdade social" (BAZOLLI, 2017, p. 50), isso com inspiração e trabaIho prático fundado no urbanismo reflexivo a partir da extensão universitária comprometida com diálogo permanente entre estudantes do ensino médio da rede estadual, acadêmicos graduandos e pós-graduandos, professores de níveis escolares variados e a comunidade em geral.

$\mathrm{Na}$ essência se pretende desenvolver efetivamente um pensar sobre o presente e o futuro, a partir de conhecimentos interdisciplinares no sentido de refletir acerca da cidade do amanhã, intrínsecos fundamentos de laços entre o local e global atribuídos a providência cultural, de contextos urbano e natural, de mobilidade e identidade. (MORIN, 2011).

Dentro deste contexto complexo este artigo intui, a partir do próximo tópico, mostrar o percurso metodológico para a construção da pesquisa sobre este projeto inovador, onde se buscou examinar o desenvolvimento das atividades e ações realizadas no município de Palmas -TO, durante o ano de 2017, na execução da extensão universitária "Nós propomos".

\section{CONHECENDO O PROJETO “NÓS PROPOMOS" E SEU PERCURSO METODOLÓGICO}

O projeto "Nós propomos" de origem portuguesa foi implantado em 2011 pelo Instituto de Geografia e Ordenamento do Território da Universidade de Lisboa (IGOT-UL), expandiu-se para a Espanha, Colômbia, Peru, Moçambique e Brasil, demonstrado na (Figura 1), por representar um instrumento que busca o despertar a cidadania ativa com enfoque na gestão democrática das cidades. (BAZOLLI, 2017, pp. 5-6 e 13-27). 
Figura 1 - Expansão do projeto "Nós propomos"

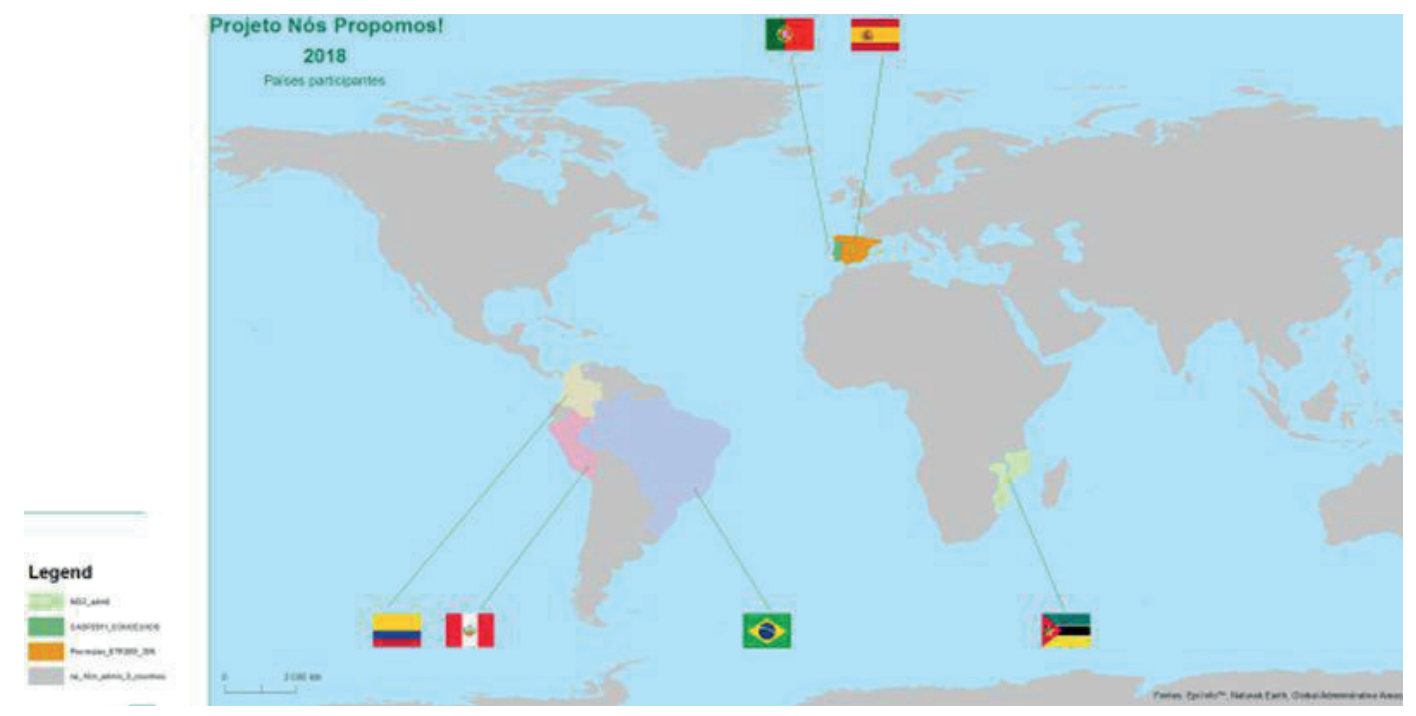

Fonte: Epi INFO'TM, Naturak Earth, Global Administrativo Áreas

Em 2016 foi implantado no Estado do Tocantins na Universidade Federal, por uma equipe interdisciplinar, para ser desenvolvido nas escolas de ensino médio das cidades de Palmas, Araguaína e Gurupi, por meio da parceria firmada com a Secretaria de Educação, Juventude e Esportes do Estado. (BAZOLLI, 2017, pp. 5-6 e 13-27).

A equipe interdisciplinar mencionada anteriormente foi formada de professores e alunos oriundos dos cursos de Direito, Arquitetura e Urbanismo, Geografia/Araguaína e do Programa de Pós-Graduação em Desenvolvimento Regional.

Essa integração entre estes cursos mostra um importante diferencial do "Nós propomos" no Tocantins. Não se tem notícias desta pratica em outras entidades que integram a rede. Ressalta-se a importância desta prática na educação interdisciplinar por estimular a participação de alunos e de professores nessa proposta inovadora extensionista.

Desta maneira, os alunos graduandos e pós-graduandos, que recebem apoio técnico-científico dos professores universitários, auxiliam o desenvolvimento das atividades do projeto nas escolas de ensino médio. As ações e atividades desenvolvidas são articuladas a partir de eventos, como: palestras, seminários, reuniões de trabalho ou mesmo na orientação de como elaborar projetos e planos de ação, que dizem respeito aos problemas locais que requerem atenção dos gestores públicos municipais.

O "Nós propomos" tem uma metodologia definida a partir do nivelamento dos universitários (graduandos e pós-graduandos da Universidade Federal do Tocantins) e dos alunos das escolas de ensino médio, para a ambientação dos pontos estruturais da proposta 
de extensão, que se desenvolvem com o auxílio de um planejamento anual de atividades, conforme orientações do manual (BAZOLLI, 2018) e o esquema demonstrado abaixo na (Figura 2), onde constam os procedimentos a serem observados pelas escolas parceiras, dessa denominada plataforma de trabalho.

igura 2 - Esquema metodológico
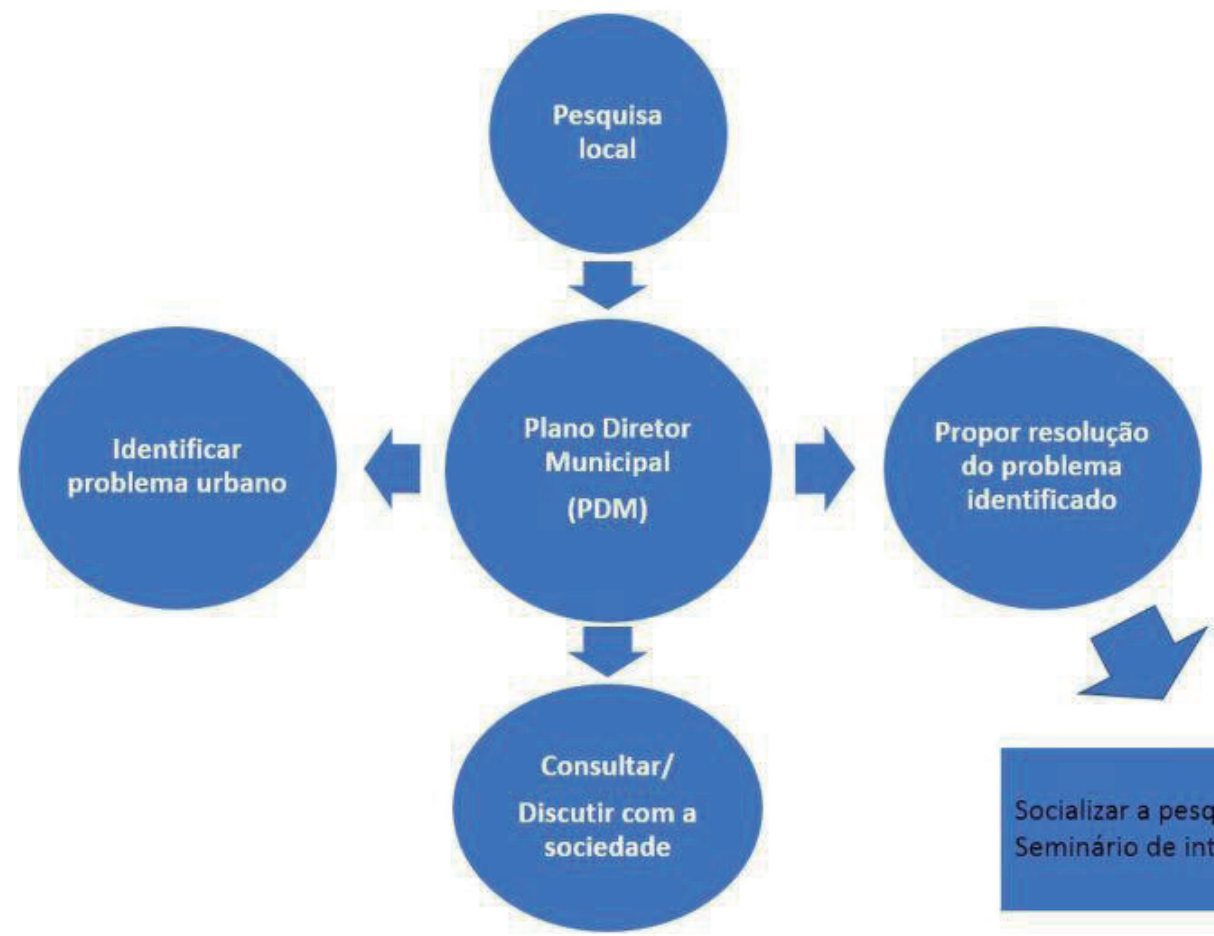

Fonte: (BAZOLLI, 2018, p. 19)

Desta maneira, as escolas formam grupos de trabalho, os quais contam com o assessoramento técnico-científico dos professores, alunos graduandos e pós-graduandos da Universidade Federal do Tocantins. Os grupos de trabalho são orientados à realização de pesquisas em fontes bibliográficas disponíveis nas escolas e na universidade.

Após estas instruções iniciais, os grupos partem para o trabalho de campo para identificar o problema urbano. E, nesta oportunidade se aproximam da comunidade e passam a conhecer a história de vida local, o "espaço vivido" na cidade, na concepção de Henri Lefebvre, a sociedade é lacunar, e seus vazios, seus abismos, também são lugares do possível. Nesta aproximação os grupos de trabalho objetivam consultar e discutir com a sociedade os problemas locais, para identificar o objeto, o problema urbano que aflige os moradores.

Detecta-se então, neste estágio, a relevância do "Nós propomos" como instrumento de articulação da participação popular. Neste momento os alunos estreitam os laços comu- 
nitários, tomam conhecimento dos problemas sociais, culturais e da realidade econômica da sua região. Desta maneira, passam a se inserir e reconstruir a consciência de "pertencimento", ou seja, sentem-se parte desse processo de mudança e começam a verificar que podem, por meio da educação e do trabalho coletivo, encontrar possíveis resoluções para a melhoria da qualidade dos serviços públicos locais.

Ressalta-se a importância de o aluno pesquisador, no estabelecimento destes laços comunitários, esteja desprovido de preconceitos para reconhecer o protagonismo dos sujeitos locais, independentemente de níveis de escolaridade. Assim sendo, torna-se primordial ao pesquisador se orientar pelo respeito a diversidade. Cada sujeito será dono de uma história de vida, mesmo que pareça anônima ao olhar do volume de informações produzidos na modernidade, porém, em regra geral ela terá profundidade maior que se poderia imaginar.

Este importante contato com a população local permite a elaboração de diagnósticos e o mapeamento dos pontos nevrálgicos e primordiais da comunidade a serem trabalhados e estudados nas rodas de palestras, reuniões de trabalho e seminários, que são realizados nas próprias escolas ou na universidade e/ou pela coordenação e equipe técnica do projeto. Estas atividades tem a finalidade de tirar dúvidas e otimizar as pesquisas realizadas pelos grupos de trabalho das escolas secundárias.

Nessa ocasião, cada equipe de trabalho conhece e seleciona o acervo de livros, revistas, documentos normativos que podem auxiliar na elaboração dos pré-projetos (propostas) e potencializar o encaminhamento de possíveis soluções para os problemas sociais diagnosticados no espaço urbano de suas comunidades.

No decorrer das atividades da edição de 2017 do "Nós propomos", ao trilhar essa linha estratégica de publicização dos trabalhos desenvolvidos, as escolas integrantes do projeto levaram os pré-projetos ao conhecimento da sociedade, por meio de participação em eventos acadêmicos e da feira de negócios realizada no município de Palmas. Posteriormente, os alunos apresentaram o trabalho final no Seminário estadual que encerrou a edição.

Esses espaços ampliados de debate oportunizaram o engajamento das equipes e proporcionaram formular propostas de melhoria da qualidade dos serviços urbanos do município de Palmas-TO.

Estas exposições dos trabalhos pelos estudantes do ensino médio foram precedidas de palestras com a participação dos alunos do Programa de Pós-Graduação em Desenvolvimento Regional da Universidade Federal do Tocantins, concernentes às temáticas: Política Pública, Estatuto da Cidade, Plano-Diretor, Urbanismo, Cidadania e Participação Democrática. Também 
aconteceram vários momentos de integração com os alunos da graduação dos diversos cursos que integram o projeto. Por fim, como já referido anteriormente, as atividades do "Nós propomos" se concluíram com a realização do II Seminário Estadual, ocorrido em novembro de 2017.

Este evento de encerramento anual da edição foi desenvolvido pedagogicamente para que os alunos fizessem as exposições das propostas de resoluções de problemas urbanos identificados na comunidade. Pode-se afirmar, fundamentado nos documentos resultantes desta atividade, que as propostas apresentadas revelaram como característica central a participação de atores sociais comunitários nas informações e sugestões de resoluções de problemas encontrados, mostrando que os alunos ao desenvolver os trabalhos buscaram articulação e integração com a população.

Assim sendo, identificou-se como ponto forte dessa atividade o ativismo criativo dos alunos, ao apontar resoluções viáveis e inovadoras para os problemas apontados nas comunidades de Palmas-TO ouvindo a população interessada. Demonstraram, também, que a gestão pública deveria planejar espaços urbanos de qualidade, com baixo investimento e respeito ao meio ambiente, a partir da escuta dos atores locais.

Ademais, os espaços urbanos planejados de forma coletiva, consciente e racional supõem "uma resposta pronta e adequada às demandas dos agentes, de modo a permitir que o encontro entre a ação pretendida e o objeto disponível se dê com o máximo de eficácia”. (SANTOS, 2006, p. 204).

Importante frisar que, por iniciativa dos alunos secundaristas, algumas dessas propostas, apresentadas no Seminário Estadual, já foram protocolizadas na Câmara Municipal e na Prefeitura de Palmas. Agregaram-se ao ofício dirigido ao legislativo e ao executivo, gráficos e maquetes, na tentativa de mostrar como deveriam ser estruturados os espaços urbanos, referindo-se à construção de praças, centro de convivência para idosos, parques, bebedouros públicos, recuperação das margens de rios e/ou córregos, dentre demais proposições de melhoria para a cidade.

A partir da análise dos elementos reunidos deste conjunto de ações realizadas pelo "Nós propomos", percebeu-se que a extensão universitária poderá se constituir como ferramenta para instigar a gestão participativa e de inclusão de jovens estudantes, se tornando uma excelente alternativa, não formal, de participação social. Constatou-se ter havido, nesse ambiente de compartilhamento de saberes popular, técnico e científico, otimização da discussão e da aprendizagem.

Assim, verificou-se que, por meio do desenvolvimento prático do "Nós propomos", os alunos das escolas de ensino médio, ao trabalhar com a realidade comunitária, foram se 
entusiasmando e resgatando o espírito proativo de pertencimento e responsabilidade pelos problemas da sua cidade. O que demonstra a "importância da extensão universitária como veículo indutor da cidadania" (BAZOLLI, 2017, p. 13-27) e possibilita entender que "ensinar não é transferir conhecimento, mas criar as possibilidades para a sua própria produção ou a sua construção". (FREIRE, 2018, p. 47).

\section{O CAMINHO PARA A DEMOCRACIA PARTICIPATIVA: DISCUSSÕES E RESULTADOS DO "NÓS PROPOMOS"}

Entender que a democracia seja modelo mais aceitável para prosseguir o objetivo mais nobre, o da sustentabilidade (ARAGÃO, 2015, pp. 23-24), impulsiona à reflexão sobre os meios alternativos adequados e não formais de participação social, tendo em vista que o modelo tradicional formal passa por desgastes na atualidade.

Vislumbra-se então, que a democracia participativa na gestão de cidades abre horizontes para a proteção das minorias; a defesa e respeito dos direitos humanos; a criação de mecanismos que garantam o acesso aos direitos essenciais à dignidade humana.

Nesse sentido, a arquitetura dialógica da esfera pública, viabilizada por Habermas (2014, p. 45) e Santos (2007, p. 10), busca restabelecer as forças motrizes da sociedade que se remodela por meio da cooperação entre as instituições do Estado e a participação dos atores sociais, com o fim de aperfeiçoar a gestão pública e racionalizar os recursos orçamentários e naturais, bem como construir espaços urbanos saudáveis e sustentáveis.

Logo, se há um cenário de desesperança e problemático que deixa a sociedade em desalento, justifica-se, por meio da extensão universitária, que sejam desenvolvidas experiências como a relatada neste artigo, justamente porque o conhecimento emancipatório desperta os atores comunitários a "pensar sobre seu papel num país de cidadãos sem direitos, em que de um lado é vítima e tem de lidar com as consequências dessa situação, e de outro pode e deve ser agente de mudanças". (DIMENSTEIN, 2012, p. 7).

Com a reestruturação de um pensar coletivo local, a comunidade terá a possibilidade de relacionar a participação formal e a gestão democrática da cidade à Constituição Federal, de 1988, diploma que trata da política urbana, executada pelo Poder Público Municipal, que objetiva ordenar o pleno desenvolvimento das funções sociais da cidade e garantir o bem-estar de seus habitantes, conforme diretrizes fixadas pelo Estatuto da Cidade, para além de reforçar a necessidade da gestão orçamentária participativa, com a realização de debates, audiências e consultas públicas sobre as propostas orçamentárias. 
Diante desse contexto, foi perceptível neste estudo a importância da construção da extensão universitária como alternativa adequada que fomenta o exercício emancipatório, pois a população que conhece seus direitos e deveres assume o espírito de cidadania, coloca-se como protagonista de sua história e empodera-se do debate público, crítico e criativo, principalmente quando chamada pelos gestores municipais e estaduais para participar de audiências públicas sobre a melhoria dos serviços sociais e o desenvolvimento regional sustentável.

Sem embargo, a "revolução democrática do direito e da justiça só faz verdadeiramente sentido no âmbito de uma revolução democrática mais ampla que inclua a democratização do Estado e da sociedade". (SANTOS, 2007, p. 10).

Assim, a extensão universitária tem o papel fundamental nesse processo dialógico entre as instituições do Estado e os atores sociais, por meio da conexão entre conhecimento científico, técnico e popular, de impor respeito e atenção às contribuições de culturas diferentes, como forma de exaltar o "exercício da ecologia de saberes", (SANTOS, 2006, p. 164) bem como recriar espaços que façam reverberar a "pedagogia da autonomia." (FREIRE, 2018, p. 39).

Com a "globalização econômica neoliberal" (SANTOS, 2002, p. 31), em que o homem tem sido levado a se tornar instrumento do consumo e do mercado, os valores como dignidade e direitos humanos são desrespeitados, é preciso, no campo das práticas capitalistas internas ou globais, a autoformação do cidadão. Segundo Santos (2002, p. 75), a desconstrução deste paradigma consiste na organização de [...] lutas que tornem possível a distribuição democrática da riqueza, ou seja, uma distribuição assente em direitos de cidadania, individuais e coletivas [...]. Portanto, a consciência de que temos o direito de ser iguais quando a diferença nos inferioriza e a ser diferentes quando a igualdade nos descaracteriza.

Nesse diapasão, a sociedade brasileira, a partir da realidade local e dos complexos problemas sociais, deve participar da reconstrução do estado democrático de direito, com fim da preservação e defesa dos direitos fundamentais albergados pela Constituição Federal de 1988.

À luz desse contexto, a Constituição Federal precisa ter força normativa e a "força normativa da Constituição depende não apenas do seu conteúdo, mas também de suas práxis". (HESSE, 1991, p. 21).

Com aporte nos resultados identificados pelo "Nós propomos", como será demonstrado na sequência do texto, pode-se afirmar que a extensão universitária se constituiu num canal de estimulo a participação social e democrática e de inclusão de jovens estudantes. 


\section{RESULTADOS DAS ATIVIDADES DESENVOLVIDAS PELAS ESCOLAS DE ENSINO MÉDIO NO MUNICÍPIO DE PALMAS-TO, EM 2017.}

Em 2017, participaram da segunda edição do "Nós propomos", na cidade de Palmas, seis escolas de ensino médio, a saber: Colégio Estadual Dom Alano, Cem Tiradentes, Colégio Estadual São José, Cem Santa Rita, Escola Estadual Liberdade, Cem Castro Alves, identificadas na (Figura 3).

Figura 3 - Mapa das escolas integrantes do projeto "Nós propomos" em Palmas.

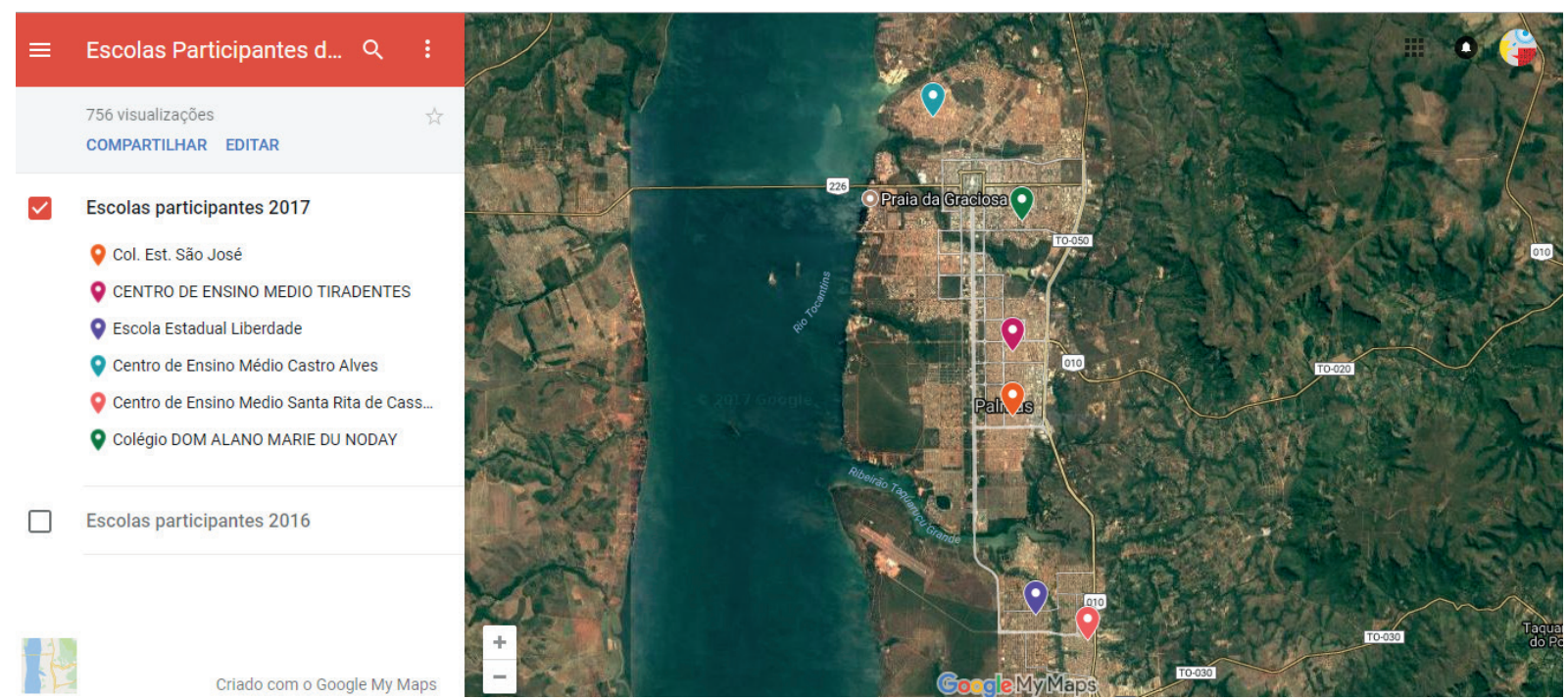

Fonte: disponível: <http://nospropomos.blogspot.com.br/>. Acesso em: 25 fev. 2018.

Das escolas participantes, foram apresentadas nove propostas com sugestões de resoluções de problemas para os serviços públicos, infraestrutura, mobilidade, segurança pública, inclusão digital, espaço público e meio ambiente, para a cidade de Palmas, conforme as proposições listadas na (Tabela 1).

Quadro 1 - Temas dos trabalhos apresentados no II Seminário "Nós propomos" (2017).

\begin{tabular}{|l|l|}
\hline \multicolumn{1}{|c|}{ TEMA } & \multicolumn{1}{|c|}{ IDENTIFICAÇÃO DA ESCOLA } \\
\hline 1. Hidrata Palmas & Colégio Estadual Dom Alano \\
\hline $\begin{array}{l}\text { 2. Sinalização horizontal e vertical da quadra } \\
806 \text { sul }\end{array}$ & CEM Tiradentes \\
\hline $\begin{array}{l}\text { 3. Pavimentação e iluminação pública da viela } \\
\text { da quadra 806 sul }\end{array}$ & CEM Tiradentes \\
\hline $\begin{array}{l}\text { 4. Limitações aos direitos de mobilidade urba- } \\
\text { na da pessoa com deficiência }\end{array}$ & CEM Tiradentes \\
\hline
\end{tabular}




\begin{tabular}{|l|l|}
\hline $\begin{array}{l}\text { 5. Acessibilidade nos arredores do Colégio } \\
\text { São José }\end{array}$ & Colégio Estadual São José \\
\hline 6. Casa de passagem viver com alegria & CEM Santa Rita \\
\hline 7. Segurança pública comunitária & Escola Estadual Liberdade \\
\hline 8. Inclusão digital e profissional & Escola Estadual Liberdade \\
\hline $\begin{array}{l}\text { 9. Praça da juventude, mais lazer e cultura, } \\
\text { mais vida }\end{array}$ & CEM Castro Alves \\
\hline
\end{tabular}

Fonte: disponível: <http://nospropomos.blogspot.com.br/.>. Acesso em: 15 mar. 2018

Como se pode denotar, os temas referenciados pelos estudantes no Seminário Estadual não são comumente objetos de atenção pelas gestões nas cidades brasileiras. Portanto, repetem-se as reivindicações da população questionando a qualidade e/ou a melhoria das políticas públicas no Brasil, especialmente as que aproximem a população do Poder público municipal.

A (Tabela 1) acima mostra que os jovens estudantes escolheram temas relevantes para a sociedade e após a escolha formaram grupos (cada equipe com cinco alunos) para estudo e pesquisa do objeto sob a orientação do professor orientador de sua escola. Neste ano (2017) analisado pelo estudo participaram diretamente do Projeto 45 (quarenta e cinco) alunos em Palmas, com repercussão interna nas escolas participantes, que atingiram indiretamente, considerando o envolvimento destes nas atividades gerais promovidas pelo projeto em mais de 500 (quinhentos) alunos.

Nesse viés de debate, para identificar o "Nós propomos" como um possível mecanismo alternativo adequado, não formal, com a finalidade de promover "a gestão democrática por meio da participação da população na execução e acompanhamento de planos, programas e projetos de desenvolvimento urbano" (Estatuto da Cidade, 2001), e como instrumento de inserção dos jovens do ensino médio das escolas da rede pública, por meio da educação à cidadania ativa, analisou-se os relatórios desenvolvidos pelos grupos de trabalho.

A análise teve enfoque no cumprimento dos objetivos gerais propostos nos relatórios entregues, a partir do conhecimento do problema identificado pelos grupos de trabalho, considerada as ações de pesquisa de cunho metodológico, observados a estratégias para chegar ao objetivo e finalmente as sugestões práticas indicativas para resolução dos problemas identificados. A síntese da análise demonstrada nas (Tabelas de 2 a 10), reforçam 
pontos importantes do envolvimento da população nas atividades do projeto e delineia o interesse dos estudantes pela resolução dos problemas identificados, nas ações desenvolvidas pelo "Nós propomos".

Quadro 2 - Proposta Hidrata Palmas

\begin{tabular}{|l|}
\hline Problema identificado \\
\hline $\begin{array}{l}\text { A falta de acesso à água potável gratuita nos centros comerciais e de maior fluxo urbano em Pal- } \\
\text { mas / TO. }\end{array}$ \\
\hline Objetivo Geral \\
\hline $\begin{array}{l}\text { Propor a implantação de bebedouros públicos em locais da Avenida Juscelino Kubitschek de Oliveira, com } \\
\text { maior fluxo de pessoas e incentivar o hábito do consumo de água. Além de contribuir com a melhoria da } \\
\text { qualidade de vida da população por meio do acesso a água potável de qualidade e gratuita. }\end{array}$ \\
\hline Ação de pesquisa \\
\hline $\begin{array}{l}\text { Referencial teórico sobre consumo de água necessário para saúde; } \\
\text { Visita a Unidade de Saúde da Prefeitura a fim de identificar possíveis problemas de saúde por falta do } \\
\text { consumo de água; } \\
\text { Entrevistas com a população que frequenta as áreas comerciais de maior fluxo em nossa capital. }\end{array}$ \\
\hline Estratégias \\
\hline $\begin{array}{l}\text { Sensibilizar os órgãos públicos competentes sobre a necessidade e a relevância social da proposta formu- } \\
\text { lada; } \\
\text { Buscar parcerias com entidades privadas de apoio a proposta; }\end{array}$ \\
\hline Sugestões práticas \\
\hline $\begin{array}{l}\text { Solicitar a direção da escola para oficiar a Câmara de Vereadores sobre a ideia de implementação de } \\
\text { bebedouros na nossa cidade; } \\
\text { Fazer valer os princípios democráticos, a fim de dar manutenção a essa ideia importante para a } \\
\text { cidade. }\end{array}$ \\
\hline
\end{tabular}

Fonte: disponível: <http://nospropomos.blogspot.com.br/.>. Acesso em: 15 mar. 2018

Quadro 3 - Sinalização horizontal e vertical da quadra 806 Sul

\section{Problema identificado}

Falta de sinalização na quadra 806 Sul afetando a mobilidade urbana para pessoas que se utilizam de meios de transportes como: ônibus coletivo, bicicleta, carro e deslocamento à pé, afetando o deslocamento dos alunos para chegar na escola, em suas casas, ao posto de saúde ou ao posto policial, identificado alto fluxo de carros e pedestres neste local.

\section{Objetivo Geral}

Propor a imediata sinalização da quadra buscando sensibilizar o Poder público e a população da urgência da medida.

\section{Ação de pesquisa}

Referencial teórico tendo como base: HONORATO, Cássio Mattos. Trânsito Seguro: Direito fundamental de segunda dimensão;

Entrevistas com os moradores e trabalhadores da quadra para obter informações e dados para contribuir na formulação da proposta;

Capacitação para os alunos da escola visando apresentar uma proposta metodológica de como colher dados, realizar entrevistas e aproveitar as vivências sobre o assunto. 


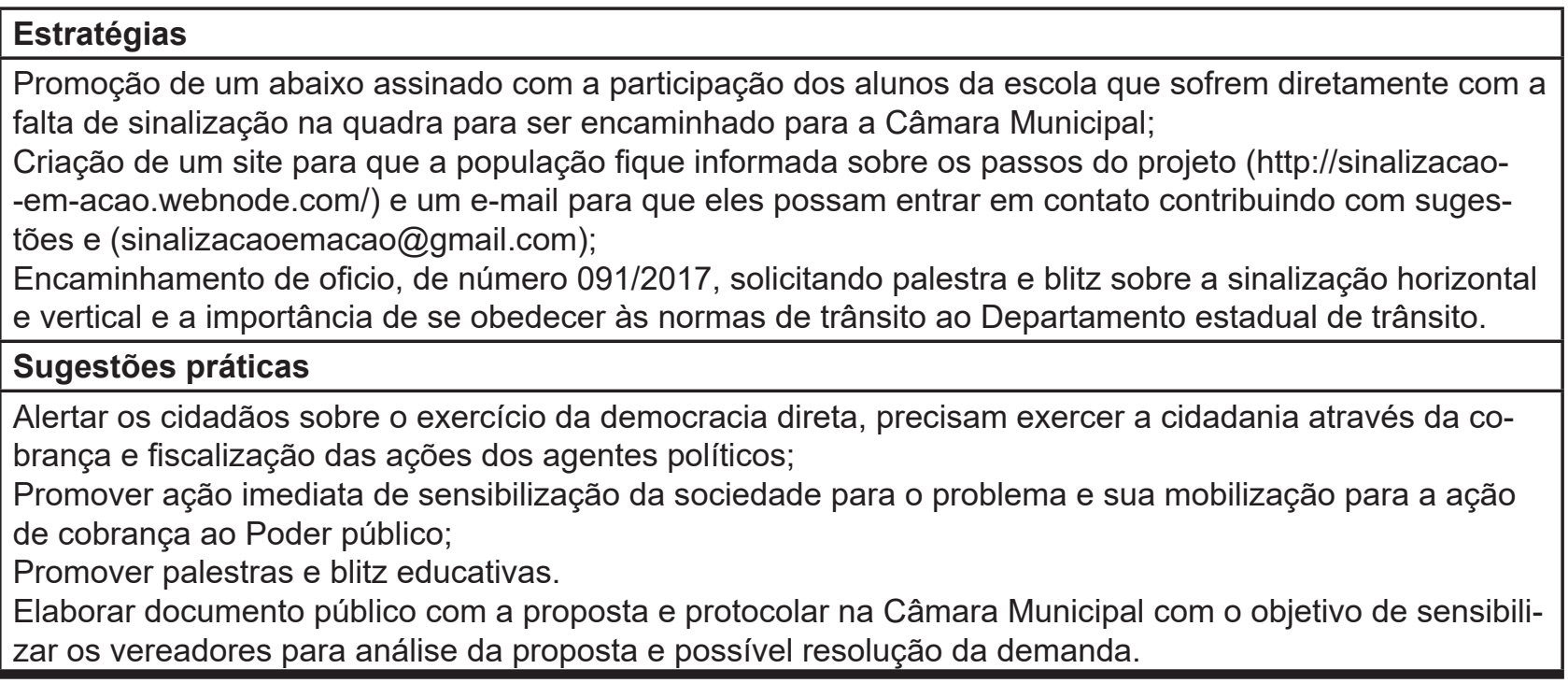

Fonte: disponível: <http://nospropomos.blogspot.com.br/.>. Acesso em: 15 mar. 2018

Quadro 4 - Pavimentação e iluminação pública da viela da quadra 806 Sul

\begin{tabular}{|l|}
\hline Problema identificado \\
\hline Ausência de pavimentação e iluminação na quadra 806 Sul \\
\hline Objetivo Geral \\
\hline $\begin{array}{l}\text { Propor a intervenção na Quadra } 806 \text { Sul, na cidade de Palmas -TO, na área chamada pelos habitantes de } \\
\text { viela, para pavimentar e iluminar este local. }\end{array}$ \\
\hline Ação de pesquisa \\
\hline Referencial bibliográfico a Lei no 10.257 , de 10 de julho de 2001 (Estatuto da Cidade) que regulamenta os \\
Art. 182 e 183 da Constituição Federal e estabelece diretrizes gerais da política urbana, tendo como base \\
o Art. $39 ;$ \\
Lei Complementar No 155, de 28 de dezembro de 2007, Plano Diretor de Palmas; \\
Visitas ao local estudado com o objetivo de entrevistar os moradores e pessoas que passavam pela viela \\
durante o período diurno e noturno com a finalidade de identificar as queixas comuns da falta de ilumina- \\
ção, asfalto, falta de segurança, assaltos frequentes, poeira no verão e lama no inverno, lixo, entre outros \\
fatores relatados pelos entrevistados; \\
Promoção de palestras ministradas pelos alunos mestrandos e graduandos da UFT ao grupo de trabalho \\
como capacitação técnica. \\
\hline Estratégias \\
\hline $\begin{array}{l}\text { Caminhada no período diurno com o objetivo de sensibilizar moradores que passavam pelo local sobre a } \\
\text { importância de mobilização popular para exigir do Poder público resolução para o problema (iluminação } \\
\text { pública e pavimentação asfáltica); } \\
\text { Caminhada no período noturno, utilizando-se de lanternas e apitos para sensibilizar e chamar a atenção } \\
\text { da comunidade no sentido de mostrar os perigos do trânsito noturno naquele local, pela falta de ilumina- } \\
\text { ção; }\end{array}$ \\
\hline Sugestões práticas \\
\hline $\begin{array}{l}\text { Açães práticas de mobilização local com o objetivo de mostrar que o Poder público não está atento ao } \\
\text { Direito à Cidade. }\end{array}$ \\
\hline
\end{tabular}

Fonte: disponível: <http://nospropomos.blogspot.com.br/.>. Acesso em: 15 mar. 2018 
Quadro 5 - Limitações aos direitos de mobilidade urbana da pessoa com deficiência

\begin{tabular}{|c|}
\hline Problema identificado \\
\hline Ausência do plano de acessibilidade na quadra 806 Sul \\
\hline Objetivo Geral \\
\hline Propor plano de acessibilidade para a quadra $806 \mathrm{Sul}$ \\
\hline Ação de pesquisa \\
\hline $\begin{array}{l}\text { Foi referencial bibliográfico o texto que foi publicado no blog do projeto "Nós propomos" elaborado pelo } \\
\text { professor orientador do grupo de trabalho, mostrando as dificuldades encontradas durante o percurso da } \\
\text { visita em campo para elaboração da proposta. Este artigo este que leva o nome do tema e foi publicado } \\
\text { no Diário da Manhã, Goiânia-GO em 29/08/2017; } \\
\text { Estudo da Lei no } 13.146 / 2015 \text {, que define que todos os municípios acima de } 20 \text { mil habitantes, precisam } \\
\text { elaborar o plano de acessibilidade; } \\
\text { Realização de atividade de campo, entrevista e coleta de informações dos moradores da quadra estuda- } \\
\text { da; } \\
\text { Promoção de palestras ministradas pelos alunos mestrandos e graduandos da UFT ao grupo de trabalho } \\
\text { como capacitação técnica. }\end{array}$ \\
\hline Estratégias \\
\hline $\begin{array}{l}\text { Criação no Instagram do endereço @papeldocidadao, que foi divulgado na unidade escolar, com o intuito } \\
\text { de alcançar uma população grande de seguidores para que o grupo de trabalho recebesse apoio para ser } \\
\text { ouvido pelo Poder público; } \\
\text { Encaminhamento ao Gabinete do Prefeito Municipal Ofício de № } 097 / 2017 \text {, no dia } 17 \text { de setembro de } \\
2017 .\end{array}$ \\
\hline Sugestões práticas \\
\hline $\begin{array}{l}\text { A partir da Lei } n^{\circ} 13.146 / 2015 \text {, que obriga a todos os municípios acima de } 20 \text { mil habitantes a elaborar o } \\
\text { plano de acessibilidade, sugere-se conscientizar a sociedade de seu papel, enquanto cidadão, de cobran- } \\
\text { ça ao Poder público, para que execute as ações necessárias no plano diretor em relação a acessibilidade } \\
\text { com a finalidade de garantir o direito de ir e vir de todas as pessoas. }\end{array}$ \\
\hline
\end{tabular}

Fonte: disponível: <http://nospropomos.blogspot.com.br/.>. Acesso em: 15 mar. 2018

Quadro 6 - Acessibilidade nos arredores do Colégio São José

\begin{tabular}{|l|}
\hline Problema identificado \\
\hline $\begin{array}{l}\text { A falta de Acessibilidade ao redor do colégio, tais como: piso tátil, rampas para cadeirantes, barras de } \\
\text { apoio, material didático que atenda as diversas necessidades. }\end{array}$ \\
\hline Objetivo Geral \\
\hline $\begin{array}{l}\text { Sensibilizar a comunidade escolar e os diversos segmentos da sociedade sobre o desafio de um sistema } \\
\text { educacional inclusivo e propor a criação de condições que garantam o acesso sem barreiras a ambientes, } \\
\text { serviços e informações para qualquer pessoa. }\end{array}$ \\
\hline Ação de pesquisa \\
\hline $\begin{array}{l}\text { Pesquisa ao referencial teórico sobre o tema, inclusive legislações; } \\
\text { Entrevistas a pessoas em situações de privações físicas; } \\
\text { Tabulação de dados da pesquisa; } \\
\text { Promoção de palestras ministradas pelos alunos mestrandos e graduandos da UFT ao grupo de trabalho } \\
\text { como capacitação técnica. }\end{array}$ \\
\hline Estratégias \\
\hline $\begin{array}{l}\text { Promover pesquisas internas para adesão de todos os membros da comunidade local; } \\
\text { Apresentação da proposta de melhoria da acessibilidade no ambiente escolar. }\end{array}$ \\
\hline
\end{tabular}


Extensão universitária ferramenta de participação social...

\section{Sugestões práticas}

Estimular pesquisas sob o assunto na cidade de Palmas TO;

Implementar: placas em Braille para identificação dos ambientes; Instalação de corrimões e pisos táteis; Aquisição de livros e jogos Braille.

Fonte: disponível: <http://nospropomos.blogspot.com.br/.>. Acesso em: 15 mar. 2018

Quadro 7 - Casa de passagem viver com alegria

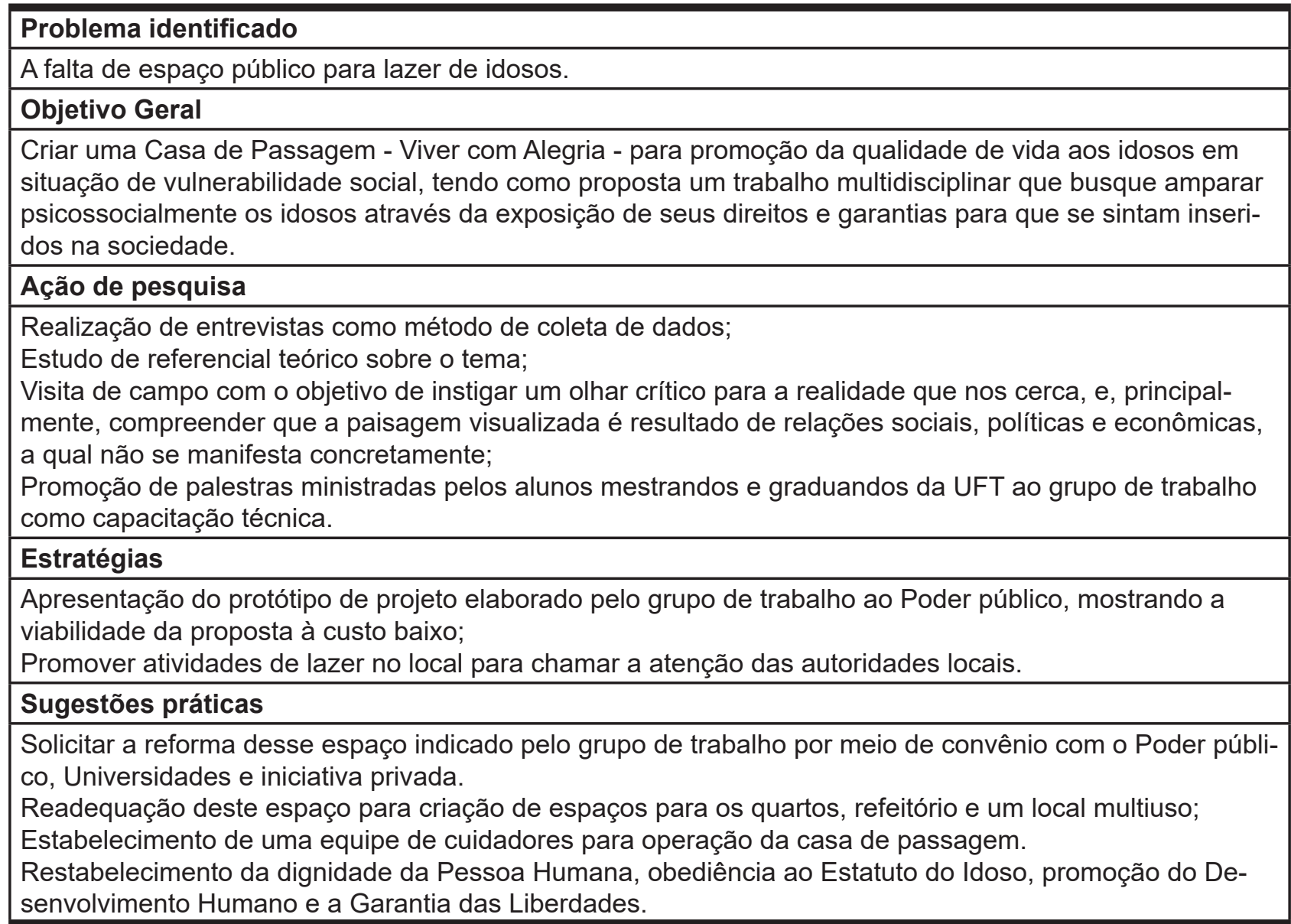

Fonte: disponível: <http://nospropomos.blogspot.com.br/.>. Acesso em: 15 mar. 2018

Quadro 8 - Segurança pública comunitária

\section{Problema identificado}

A falta de Segurança Pública Comunitária e consequente aumento da violência no bairro da Aureny III em Palmas.

\section{Objetivo Geral}

Criar a justiça comunitária, a partir de uma nova visão social da Segurança Pública, preventiva, pelo uso da mediação de conflitos e que leve em conta questões sociais e econômicas.

Ação de pesquisa 
Foi realizada pesquisa de campo com a comunidade, e o resultado foi que $72 \%$ da população entrevistada considera urgente e importante a questão sobre segurança dentre outros temas;

Estudo de referencial teórico sobre o tema;

Promoção de palestras ministradas pelos alunos mestrandos e graduandos da UFT ao grupo de trabalho como capacitação técnica.

\section{Estratégias}

Efetivação de parceria com o $6^{\circ}$ batalhão da Polícia Militar e se encontra em construção um aplicativo de Segurança Comunitária a ser usado pela população local;

Realização de palestras sobre o assunto para alunos e pais;

Realização de panfletagem no Bairro da Aureny III, visitas em escolas públicas e privadas da cidade com informativo sobre segurança Pública;

Carta ao Poder público, mostrando a viabilidade da proposta à custo baixo;

Promoção de atividades de lazer no local para chamar a atenção das autoridades locais.

\section{Sugestões práticas}

Estabelecer um convênio com a Defensoria Pública Estadual para a instalação da Justiça Comunitária em razão da instituição ter um projeto voltado para este tipo de ação.

Fonte: disponível: <http://nospropomos.blogspot.com.br/.>. Acesso em: 15 mar. 2018

Quadro 9 - Inclusão digital e profissional

\section{Problema identificado}

A falta de espaços virtuais para uso público provocou o interesse nos estudantes de reabrir o Palmas Virtual localizado no Bairro da Aureny III em Palmas.

\section{Objetivo Geral}

Reativar o espaço Palmas Virtual, no bairro Aureny III, para atender a comunidade local com cursos de qualificação profissional e inclusão digital.

\section{Ação de pesquisa}

Foi realizada pesquisa de campo com a comunidade, e o resultado foi de 83 moradores do entorno do Palmas Virtual querem a sua reativação;

Estudo de referencial teórico sobre o tema;

Promoção de palestras ministradas pelos alunos mestrandos e graduandos da UFT ao grupo de trabalho como capacitação técnica.

\section{Estratégias}

Estabelecimento de parceria com órgãos competentes;

Solicitação da reabertura do espaço público Palmas Virtual;

Elaboração de Plano de trabalho para o funcionamento do Palmas Virtual;

Distribuição de carta aberta a população a fim de reafirmar a importância da reabertura do espaço.

\section{Sugestões práticas}

Estabelecer diálogo aberto entre escola e comunidade a fim de buscar estratégias para a resolução do problema;

Buscar parceria com a Prefeitura da cidade responsável pelo equipamento urbano.

Fonte: disponível: <http://nospropomos.blogspot.com.br/.>. Acesso em: 15 mar. 2018

Quadro 10 - Praça da juventude, mais lazer e cultura, mais vida

\section{Problema identificado}

A falta de espaços públicos de lazer para a juventude. 


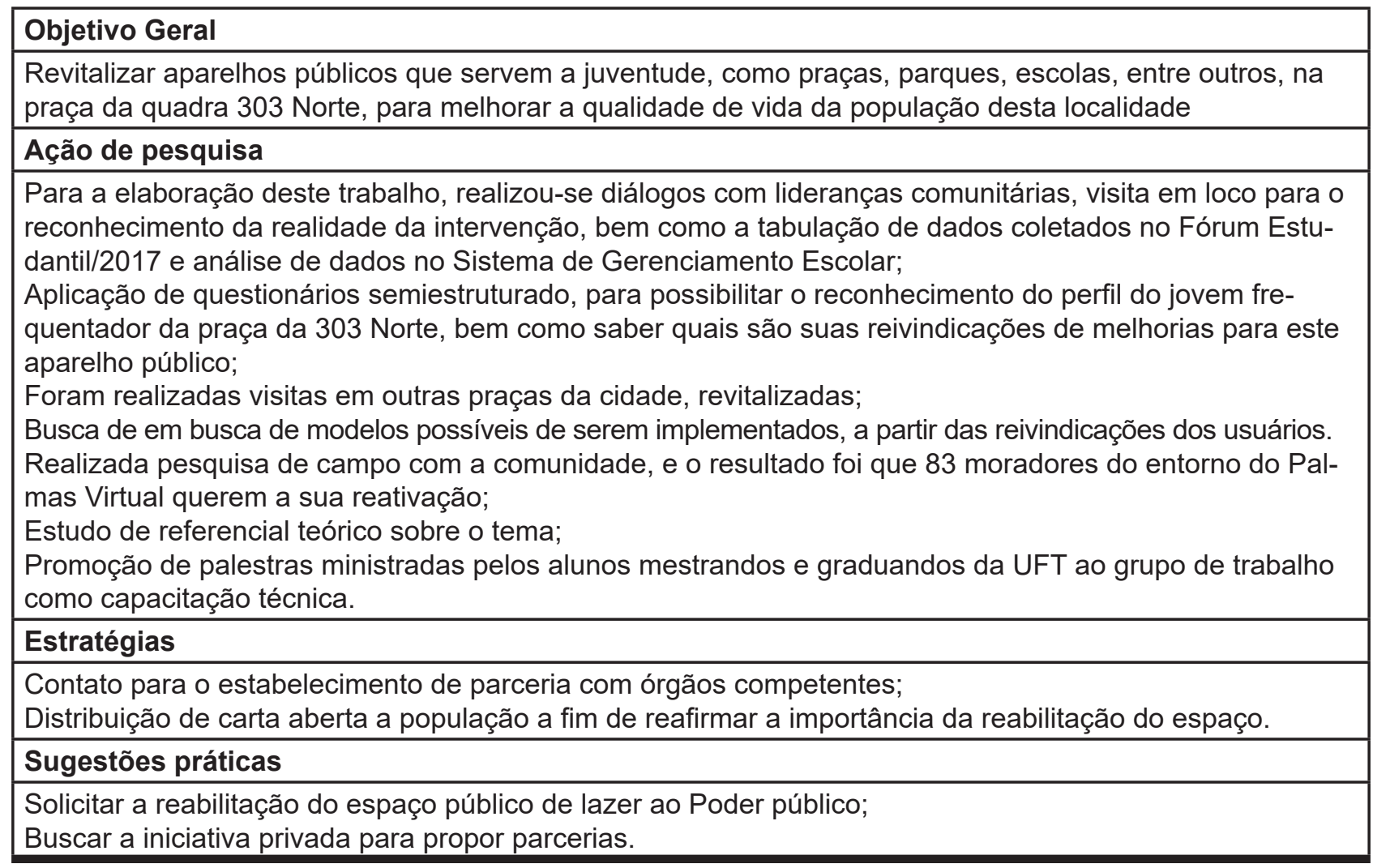

Fonte: disponível: <http://nospropomos.blogspot.com.br/.>. Acesso em: 15 mar. 2018

Neste estudo foram acompanhadas todas as atividades do projeto realizadas pelos alunos, como: visitas comunitárias; encontros técnicos; palestras; reuniões de trabalho e outros eventos. Os alunos secundaristas apresentaram os seus trabalhos constituídos de propostas de resoluções de problemas urbanos em duas oportunidades: a primeira em setembro para qualificar e coletar novas sugestões sobre o desenvolvimento do trabalho e a segunda em novembro, para avaliação final, demonstrado na (Figura 4).

Figura 4 - Seminário Estadual realizado no dia 13 de novembro de 2017

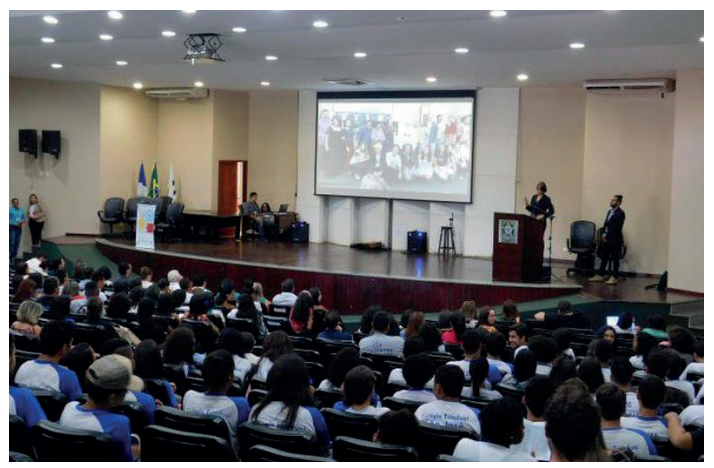

Fonte: Foto acervo dos autores 
Em ambas apresentações os trabalhos foram avaliados por experts e estabelecidos 10 (dez) critérios para análise e atribuídas notas na escala de 0 (zero) a 10 (dez) pontos, conforme demonstrado na Tabela 11.

Quadro 11 - Tabela de critérios de avaliação

\begin{tabular}{|c|c|}
\hline N. & CRITÉRIOS \\
\hline 1 & $\begin{array}{l}\text { O trabalho está plenamente adequado ao tema proposto (referindo-se ao conteúdo apresen- } \\
\text { tado - deverá estar vinculado às questões urbanas). 0-10 pontos }\end{array}$ \\
\hline 2 & $\begin{array}{l}\text { A proposta é criativa (mostra a capacidade de produzir efeitos e transformar o ambiente se- } \\
\text { gundo as necessidades comunitárias). } 0-10 \text { pontos }\end{array}$ \\
\hline 3 & $\begin{array}{l}\text { A proposta é inovadora (demonstra mudança de processo no tratamento das questões urba- } \\
\text { nas e reflete pequenas melhorias e avanços nos benefícios proporcionados para a comunida- } \\
\text { de). 0-10 pontos }\end{array}$ \\
\hline 4 & $\begin{array}{l}\text { A proposta é viável (análise subjetiva - Política, Social, Operacional - se a proposta pode ser } \\
\text { exequível, alcançar os resultados esperados e ter êxito na sua aplicação). 0-10 pontos }\end{array}$ \\
\hline 5 & $\begin{array}{l}\text { Grau de impacto da proposta na comunidade (análise subjetiva - melhoria substantiva - se a } \\
\text { proposta poderá representar mudança substancial na melhoria da qualidade de vida na comu- } \\
\text { nidade). } 0-10 \text { pontos }\end{array}$ \\
\hline 6 & $\begin{array}{l}\text { Participação social (a proposta demonstra que a comunidade estará envolvida na formulação, } \\
\text { implantação e acompanhamento). 0-10 pontos }\end{array}$ \\
\hline 7 & $\begin{array}{l}\text { A proposta é consistente (análise subjetiva se a proposta delimita claramente o objeto de } \\
\text { estudo, possui lógica, é razoável, apresenta critica razoável). 0-10 pontos }\end{array}$ \\
\hline 8 & O grupo apresentou o trabalho com clareza na linguagem oral. 0-10 pontos \\
\hline 9 & $\begin{array}{l}\text { O conteúdo do trabalho (Slides) foi apresentado com redação estruturada e organizada de } \\
\text { maneira lógica das partes. } 0-10 \text { pontos }\end{array}$ \\
\hline 10 & $\begin{array}{l}\text { Segurança na defesa da ideia (o grupo foi seguro na apresentação, defendeu a proposta de } \\
\text { maneira veemente, acredita na concretização e operacionalização, o problema identificado } \\
\text { pelo grupo está sendo atendido pela proposta de resolução). 0-10 pontos }\end{array}$ \\
\hline
\end{tabular}

Fonte: Elaborada pelos autores

Foram convidadas 24 (vinte e quatro) pessoas ligadas ao tema "urbano" exercendo atividades acadêmicas, comunitárias, empresariais; outras atuando em movimentos sociais, instituições profissionais, como profissionais autônomos e profissionais da educação, para avaliar os trabalhos apresentados. Em análise a percepção dos avaliadores, considerando-se as duas apresentações mencionadas anteriormente, obteve-se entre os itens da (Tabela 11) incidências significativas, classificadas pelas maiores notas, os critérios 5, 6 e 10 conforme demonstrados na (Tabela 12).

Quadro 12 - Tabela de critérios de avaliação

\begin{tabular}{|c|l|c|}
\hline N. & \multicolumn{1}{|c|}{ CRITÉRIOS } & NOTAS \\
\hline 5 & $\begin{array}{l}\text { Grau de impacto da proposta na comunidade (análise subjetiva - melhoria subs- } \\
\text { tantiva - se a proposta poderá representar mudança substancial na melhoria da } \\
\text { qualidade de vida na comunidade }\end{array}$ & 9,29 \\
\hline
\end{tabular}




\begin{tabular}{|c|l|c|}
\hline 6 & $\begin{array}{l}\text { Participação social (a proposta demonstra que a comunidade estará envolvida na } \\
\text { formulação, implantação e acompanhamento) }\end{array}$ & 8,71 \\
\hline 10 & $\begin{array}{l}\text { Segurança na defesa da ideia (o grupo foi seguro na apresentação, defendeu a } \\
\text { proposta de maneira veemente, acredita na concretização e operacionalização, o } \\
\text { problema identificado pelo grupo está sendo atendido pela proposta de resolução) }\end{array}$ & 9,00 \\
\hline
\end{tabular}

Fonte: Elaborada pelos autores

Como resultado se destaca que, seguindo a análise proposta a partir de observações às notas aplicadas pelos avaliadores na escala de 0 (zero) a 10 (dez) pontos atribuídos aos critérios mostrados na (Tabela 11), dadas às escolas que apresentaram suas propostas nos seminários, nos eventos já mencionados anteriormente, a pesquisa atingiu seu objetivo de compreender a extensão universitária como meio de instigar estudantes do ensino médio a participação social. Deve-se pontuar que as apresentações foram subsidiadas por resumos elaborados pelos alunos julgados, demonstrados nas Tabelas de 2 a 10, explicando tecnicamente as propostas apresentadas, para além disso, foram realizadas entrevistas com os avaliadores buscando entender o enfoque individual aplicado às avaliações. Portanto, em consonância ao objetivo proposto pelo trabalho se constatou que os alunos procuraram dialogar com a comunidade local, que demonstraram compreensão acerca da participação social e que acreditam na concretização e operacionalização das propostas de resolução de problemas por eles sugeridas, conforme demonstra a (Tabela 12), itens 5, 6 e 10.

Desta maneira, levando-se em conta os dez critérios mostrados pela (Tabela 11) foi possível deduzir que houve impacto significativo do projeto "Nós propomos" sobre a comunidade local (a nota atribuída ao critério foi de 9,29 pontos), percebeu-se o despertar da participação social durante as atividades propostas pelo projeto (a nota atribuída ao critério foi de 8,71 pontos) e a demonstração de que os alunos acreditam na viabilização e na concretização de suas propostas que apresentadas nos eventos (a nota atribuída ao critério foi de 9,00 pontos), demonstrados na (Tabela 12).

Em análise as tabelas de 2 a 10, os pontos destacados são reafirmados, demonstrando que o sustentáculo das atividades do "Nós propomos" esteve na participação comunitária, através de entrevistas, questionários, visitas técnicas e outros métodos de aproximação com a população, para a partir da escuta da comunidade identificar os problemas locais e em diálogo contínuo buscar a solução efetiva, econômica, criativa e viável, para estes problemas.

Importante salientar a considerável avaliação em escala de pontuação pela criatividade, inovação e viabilidade das propostas formuladas pelos grupos participantes do projeto. 
Fator que permitiu entender como o projeto se constitui efetivamente em modelo alternativo adequado de inserção dos jovens nos debates sobre a gestão democrática da cidade, para além disso, poderá favorecer a melhoria do planejamento urbano sustentável nas cidades e se tornar uma importante ferramenta de política de inclusão social.

\section{CONCLUSÃO}

Foi possível destacar neste trabalho a necessidade de séria reflexão sobre a escassez de políticas públicas aplicadas para resolução de problemas nos municípios brasileiros, para além disso, o processo de politização e avanço da democracia direta requer a descolonização do Poder público e a inclusão da sociedade nas discussões, planejamento e fiscalização da gestão do município.

Como destaque este trabalho apontou que a luta por espaços dignos à vida em comunidade não pode ser concretizada sem a escuta e colaboração da população, conforme demonstrado nas discussões e nos resultados relatados e apresentados por este estudo.

Neste sentido, à guisa de conclusão a partir do exame do percurso metodológico das atividades desenvolvidas pelo projeto de extensão "Nós propomos" desenvolvido pela Universidade Federal do Tocantins, constata-se que este mecanismo, não formal, de participação social apresenta-se como modelo alternativo adequado de inserção dos jovens nos debates sobre a gestão democrática da cidade e que poderá favorecer a melhoria do planejamento urbano sustentável, possibilita a criação de políticas públicas de inclusão social, propicia a otimização dos recursos orçamentários e contribui para o desenvolvimento da região norte do Brasil.

Sugere-se então, conjugar o debate do "Nós propomos" ao tema da Educação Integral com a finalidade de tentar compreender se a educação poderia ser vista como um elemento norteador de políticas públicas, na busca de garantir condições de igualdade, de valorização da diversidade intrínseca à vida na cidade e sua intencionalidade educativa nos diferentes aspectos da sua organização, como: do planejamento urbano, da participação, dos processos decisórios, da ocupação dos espaços e equipamentos públicos, do meio ambiente, das ofertas culturais, recreativas e tecnológicas.

Contata-se neste estudo que a educação se constitui mecanismo de empoderamento de sujeitos de direito nas comunidades que vivem, a partir de uma contemporaneidade marcada por intensas transformações e exigências crescentes de acesso ao conhecimento.

Desta maneira, pode-se concluir também, que as transformações, mesmo assim, não se efetivam na velocidade desejada, em razão dos efeitos das mudanças se revelarem 
por exposições exacerbadas e proporcionarem resistências conservadoras, num molde curricular segregador.

Buscou-se neste estudo contextualizar a ideia da construção de uma escola pública inovadora, que possibilitasse que as pessoas se reconhecessem e se apropriassem dos espaços públicos e culturais, vendo neles oportunidades de aprendizagem.

E, nessa perspectiva, de reconhecimento e apropriação, a cidade poderia ser pensada como parte integrante do currículo escolar e não algo à parte, como acontece na maioria das escolas brasileiras.

Embora a escola ainda seja vista somente a partir da perspectiva do ensino, dos professores, dos estudantes, sem conectá-la às discussões de ocupação da cidade, o projeto "Nós propomos" sugere quase uma institucionalização da vida urbana no espaço escolar. O projeto é considerado atualmente um difusor de urbanidade e traz a cidade para dentro da escola, uma relação é fundamental.

Pretende-se com este trabalho subsidiar estudos futuros voltados para a abordagem de Educação Integral, ligada a duas condições fundamentais: ampliação do tempo dos estudantes na escola e a diversificação da oferta educativa dentro do ambiente escolar.

\section{REFERÊNCIAS}

ARAGÃO, Alexandra. Introdução. In. ; BESTER, Gisela Maria e HILÁRIO, Gloriete Marques Alves. (Coords.). Direito e ambiente para uma democracia sustentável: diálogos multidisciplinares entre Portugal e Brasil. Curitiba: Instituto Memória, 2015.

ARENDT, Hannah. A condição humana. Tradução de Roberto Raposo. 10. ed. Rio de Janeiro: Forense Universitária, 2007.

BAUMAN, Zygmunt. Tempos líquidos. Tradução Carlos Alberto Medeiros. Rio de Janeiro: Zahar, 2007.

BAUMAN, Zygmunt. BORDONI, Carlo. Estado de crise. Tradução Renato Aguiar. Rio de Janeiro: Zahar, 2016.

BAZOLLI, J.A. et al. (Coord.). Manual Nós propomos. Disponível em: http://nospropomos. blogs. pot.com.br/2017/12/nospropomos-lanca-manual-para-orientar.html?=1. Acesso em: 25 fev. 2018. 
A extensão universitária como indutora à cidadania: a experiência do "Nós propomos". Palmas: EDUFT, 2017.

O papel da extensão universitária como indutora da participação social: Palmas Participa! Palmas: EDUFT, 2017.

BRASIL. Constituição da República Federativa do Brasil, 1988. Org. do texto: Juarez de Oliveira. 4. ed. São Paulo: Saraiva, 1990. (Série Legislação Brasileira).

Lei $n^{0}$ 10.257, de 10 de julho de 2001. Estatuto da cidade. Regulamenta os arts. 182 e 183 da Constituição Federal, estabelece diretrizes da política urbana e dá outras providências. Disponível em: https://www.planalto.gov.br/ccivil_03/Leis/LEIS_2001/L10257. htm. Acesso em: 18 jan. 2018.

DIMENSTEIN, Gilberto. O cidadão de papel: a adolescência e os direitos humanos no Brasil. 24. ed. São Paulo: Ática, 2012.

FREIRE, Paulo. Pedagogia da autonomia: saberes necessários à prática educativa. 56 ${ }^{a}$ ed. São Paulo: Paz e Terra, 2018.

HABERMAS, Jürgen. Teoria do agir comunicativo. Vol. 2: racionalidade da ação e racionalização social. Tradução Paulo Astor Soethe; revisão da tradução Flávio Beno Siebeneichler. São Paulo: Editora WMF Martins Fontes, 2012.

Mudança estrutural da esfera pública: investigações sobre uma categoria da sociedade burguesa. Tradução Denilson Luís Werle. 1. ed. São Paulo: Editora Unesp, 2014. HESSE, Konrad. A força normativa da constituição. Tradução de Gilmar Ferreira Mendes. Porto Alegre: Sergio Antonio Fabris Editor, 1991.

MORIN, Edgar. Os sete saberes necessários à educação do futuro. Tradução Catarina Eleonora F. da Silva \& Jeanne Sawaya. 4. ed. São Paulo: Cortez, Brasília, DF:UNESCO, 2001.

A cabeça bem-feita: repensar a reforma, reforma o pensamento. Tradução Eloá Jacobina; 8. ed. Rio de Janeiro: Bertrand Brasil, 2003.

A via para o futuro da humanidade. Rio de Janeiro: Bertrand Brasil, 2011.

SANTOS, Boaventura de Sousa. A globalização e as ciências sociais. 2. ed. São Paulo: Cortez, 2002. 
A gramática do tempo: para uma nova cultura política. São Paulo: Cortez, 2006.

Para uma revolução democrática da justiça. São Paulo: Cortez, 2007.

SANTOS, Milton. A natureza do espaço: técnica e tempo, razão e emoção. 4. ed. São Paulo: Editora da Universidade de São Paulo, 2006. 